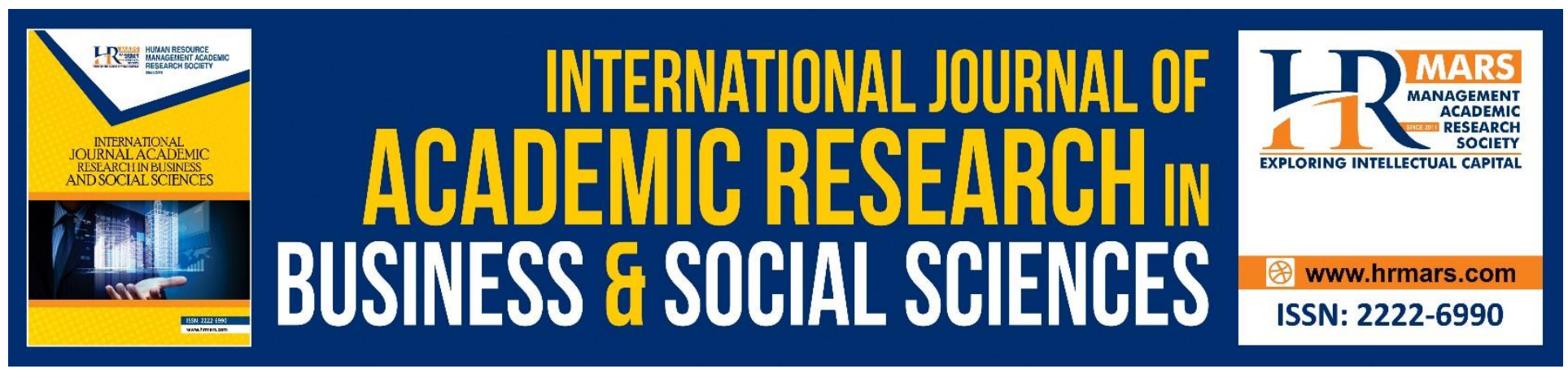

\title{
The Effect of Tax Communication on Taxpayers Attitude
}

\author{
Banu Dincer \\ Caner Dincer
}

To Link this Article: http://dx.doi.org/10.6007/IJARBSS/v8-i12/5178

DOI: $10.6007 /$ IJARBSS/v8-i12/5178

Received: 03 Nov 2018, Revised: 19 Dec 2018, Accepted: 30 Dec 2018

Published Online: 31 Dec 2018

In-Text Citation: (Dincer \& Dincer, 2018)

To Cite this Article: Dincer, B., \& Dincer, C. (2018). The Effect of Tax Communication on Taxpayers Attitude. International Journal of Academic Research in Business and Social Sciences, 8(12), 1137-1143.

Copyright: (C) 2018 The Author(s)

Published by Human Resource Management Academic Research Society (www.hrmars.com)

This article is published under the Creative Commons Attribution (CC BY 4.0) license. Anyone may reproduce, distribute, translate and create derivative works of this article (for both commercial and non-commercial purposes), subject to full attribution to the original publication and authors. The full terms of this license may be seen at: $\underline{\text { http://creativecommons.org/licences/by/4.0/legalcode }}$

Vol. 8, No. 12, 2018, Pg. 1137 - 1143

http://hrmars.com/index.php/pages/detail/IJARBSS

JOURNAL HOMEPAGE

Full Terms \& Conditions of access and use can be found at http://hrmars.com/index.php/pages/detail/publication-ethics 


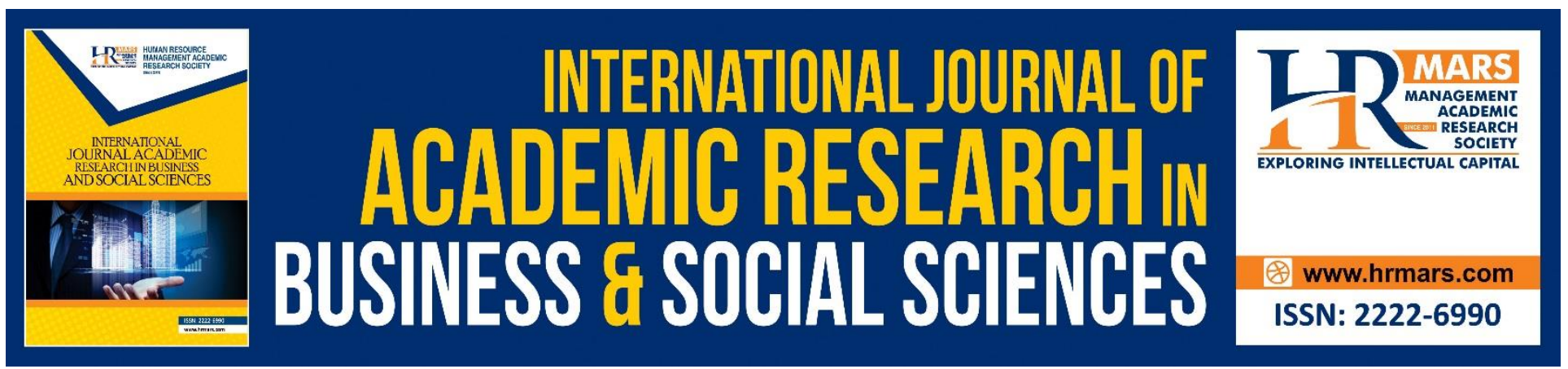

\section{The Effect of Tax Communication on Taxpayers Attitude}

\section{Banu Dincer}

Faculty of Economic and Administrative Sciences, Department of Business Administration,

Galatasaray University, Turkey.

Email: bdincer@gsu.edu.tr

\section{Caner Dincer}

Faculty of Economic and Administrative Sciences, Department of Business Administration

Galatasaray University, Turkey.

E-mail: cdincer@gsu.edu.tr

\section{Abstract}

The literature on taxpayers attitude show that taxpayers influence each other and change their tax paying attitude. However, little is known about the content and the processes providing this change. To address this knowledge gap, we employed an in-depth analysis of focus groups discussions about tax among a professionnals from construction industry. We report an empirical analysis of discussions of four groups showing 276 distinct discussions between 6 directors, 6 company owners and 22 employees to see the possible reasons in their attitude towards taxpaying, providing a four categories of persuasion. First the participants Exchange information about rules and procedures, second they focus on compliance and want others to comply, third they try to influence each other to be good citizen and persuade to comply and finally the discussions lead to warnings and threats.

Overall, this study sheds light to the effect and use of social norms, tax compliance, tax communication in social networks, and persuasive messaging in tax compliance campaigns.

Keywords: Taxpayers attitude, Tax compliance, Focus group

\section{Introduction}

Good citizens comply with tax regulations and laws and pay at the due time their taxes, however, many studies in this field showed that people are ready to avoid their tax payment can alter their behavior after a discussion with other taxpayers or when they see another taxpayer complying with regulations. The purpose of this paper is to shed light to these discussions and the behavioral change of good citizens to provide some data for regulators to find the right way of communication with taxpayers and to better persuade them in the social networks era. In order to do this an in-depth 
analysis of four focus group discussions about income tax among 6 directors, 6 company owners and 22 employees is realized. To see the possible reasons in their attitude towards tax and thechanges in their behavior ths issues ranging from taxregulations to a variety of interactions aimed at persuading defiant individuals to comply with tax laws and the persuasion techniques of regulators, the benefits of compliance, to threats of severe economic and reputational consequences are discussed. Overall, this paper investigated the social influence processes between taxpayers and their tax communication in social networks with possible outcomes.

Many large-scale studies showed that taxpayers attitude and behavior towards tax change when they discuss about this issue with others (Rincke and Traxler, 2009; Torgler, 2005). Unfortunately little is known about the content of these discussions because in general people avoid to talk about the sum they pay or the ways they avoid by fear of bad perception. In thispaper by offering a focus group environment to 34 taxpayers in four groups, we'll provide empirical insight to this social phenomenon. Professionnals are selected for discussions as they seek help about regulations, rules and others experience. Their enquiries and ideas and changes in their behavior are analyzed to have an in-depth look at the social interactions and discourses that occur between them.

Although there are many tendencies in the literature on the taxpayers interaction, these discussions highlighted 4 tendencies about taxpayers interaction. First the participants Exchange information about rules and procedures, second they focus on compliance and want others to comply, third they try to influence each other to be good citizen and persuade to comply and finally the discussions lead to warnings and threats to defiant professionals using issues like penalties and reputation loss. This work will provide directions for these tendencies and implications for further researches.

\section{Previous Research}

The links behind the tax compliance or non-compliance according to taxpayer communication embrace many factors in the literature. The taxpayer behavior is influenced from his/her beliefs about sanctions (Slemrod et al., 2001), individual values (Cummings et al., 2006; Torgler, 2002), social norms (Bobek et al., 2007), knowledge about the law (McKerchar, 1995) and tax; tax administration (Boll, 2013). Surely, taxpayer behavior ise influenced by all of these factors and even additional ones. Accordingly, communication between taxpayers can play on the perception of social norms against tax avoidance but it is also a way to learn about tax laws and sanctions. This view of taxpayer behavior is confirmed by many researchers, (Braithwaite, 2009; Kirchler et al., 2008).

The sources also differ the tendence of the taxpayer and have very different fonctions. For example, co-workers maket he taxpayer feel less guilty if they evade taxes, as they perceive themselves equal to them. However a discussion with the family has the opposite effect and strengthens the moral point of view. Rincke and Traxler (2009) affirme that communication may also affect taxpayers' perceived risk of being caught. This is also due to social norms, as they are more effective in social groups (Ostrom, 2000). In sum, two mechanisms are fundamental fort he taxpayer communication; the knowledge about audits and penalties, and perceptions of social norms. So, the communication in occupational groups offer the same perception for a group and is a good basis for exchanging information and experience as they will share the same taxpaying culture (Ashby and Webley, 2008; Ashby et al., 2009). Furthermore, they will be subject to similar regulations, obligations (Sigala et al., 1999), and opportunities (Stalans et al., 1991). 
Sigala et al. (1999) showed taht in the same business environment people exchange information to learn the correct regulations; evasion opportunities, and to pay the correct amount of tax however these issues can also be considered to be intimate so it is also very linked to the social and cultural context of the communication. Ashby and Webley (2008) confirmed this finding in the beauty industry.

Previous research on tax communication determined that this communication affects attitudes toward paying tax and compliance behavior. However, the process that explains why communication with other taxpayers affects people's behavior differs. Stalanset al. (1991) affirme that the time spent discussing tax with co-workers lowers their compliance attitudes as they learn the ways to avoid or evade tax. In contrast, Rincke and Traxler (2009) propose that communication with audited colleagues increase the rate of compliance. However, in-depth investigation of the processes that occur during taxpayer communication is still necessary. Therefore, this paper investigate realistic taxpayer communication in a focus groups.

\section{Study}

In order to investigate the interactions during discussions, we used four focus groups .this method makes it possible to observe how people use communication to perform certain social actions (Potter, 2012).Because during communication, people do not simply convey information; the communication also performs a distinct function such as a request, an apology and an influence. Our approach can show us what exactly taxpayers talk about, moreover it can let us determine the processes underlying the influence on others to comply or non-comply.

Previous studies considered taxpayers as passive transmitters and recipients of information communicating social norms, audits and sanctions. However, the information has some functions. Because a discussion about sanctions will surely be a sign of threat to another one who does not comply or avoid tax even if it is not the main topic of the discussion (Hepburn and Potter, 2011). That shows us that the social nature of these discussions and the agencyof both actors. In focus groups, we can go beyond the surface level as it offers a realistic context with naturally occurring discussions permitting us to understand how people in the same industry communicate about tax, and how they influence each other's compliance intentions.

\section{Method}

The four focus groups for data collection represent a total of 34 persons, 6 directors, 6 company owners and 22 employees. Most of the topics discussed involved advices on business, legal obligations of running a business, tax obligations, during a 90 minutes session for each group. Data were collected in March- April 2018. Especially the conversations that contain the word 'tax' are deeply investigated within transcribed and recorded discussions.

Of the larger number of discussions about tax on the four groups, we are concentrated on tax advices and compliance decisions related discussions between experienced business owners and others. Some conversations involve all participants in a group and many replies, while others may be very short and only include one or two replies. On the whole, conversations have an average of three replies and four users involved in groups of 8 and 9. 
INTERNATIONAL JOURNAL OF ACADEMIC RESEARCH IN BUSINESS AND SOCIAL SCIENCES Vol. 8, No. 12, Dec, 2018, E-ISSN: 2222-6990 @ 2018 HRMARS

Conversation analysis has been applied to analyze social interactions as they occur in every-day conversations, to perform conversation analysis we used the transcribed material and determined 276 conversations between experienced business owners and others. These conversations formed our main data for the research.

Our data analysis method draws on other applications of focus group studies. Our approach is aimed at exploring the data in detail in order to reveal patterns for further research. After selecting the tax compliance related conversations for analysis, we coded their content, grouped the similar ones and finally categorised into four tendencies; Information exchange about rules and procedures, compliance and influence others to comply, persuade to comply and finally warnings and threats to defiant professionals using issues like penalties, audits, and reputation loss.

\section{Results}

Identified four categories of tendencies will investigated to have a textual qualitative analysis and provide a framework for furture studies and implications will be discussed.

The information exchange tendency discussion starts usually with questions between participants about income tax and then general information is rapidly given from others based on their personal experiences in the business. The information deepens with procedures and registrations, rates, forms needed with the tax authority. By doing this they provide an answer and in the same time they implicitly ask for compliance with the issues that they explain. Many participants ask for confirmation of others especially when they inform about an obligation. This requesting to comply behavior can be compared with the same behavior facing social norms as suggested by Edwards, 2006. This is a usual way of communicating norms (Potter, 1996). Their subtle communication style makes their communication more persuasive and effective especially when confirmed by the majority of others in the group.

However, when the questioner is confused about the answer and questions it again, this leads to subsequent discussion as the validity of the answer is dismissed. In such a case, all the group members try to clarify the rule but if the arguing continues the respondent tries to be more persuasive. First, $\mathrm{He} / \mathrm{She}$ starts to state norms to reinforce their idea and confirm that they obey to this norm to finish the issue. Secondly, if the hesitation still continues, they start to emphasize that not paying or complying with this constitutes evasion. This is a general to people's propensity to conform to existing behaviors in society (Bobek et al., 2007). This also comes from the feeling that complying participants want others to be obliged to do so based on a norm of reciprocity (Fehr et al., 2002). A second explanation is the participants, even they transgress the tax rule discussed, they deny it in order to not to be accused and so they have defensive responses. By verbally sanctioning transgression and reinforcing the right behavior, they strengthen compliance with norms and avoid becoming target of others. These techniques reflect general methods of social influence (Cialdini and Goldstein, 2004). Another style of persuading others used in the four groups is to directly request the questioner to do what is said. Because generally, the phrases aimed at social influence and control others are said in subtle indirect ways (Potter and Wetherell, 1987). However, direct request is also possible but in this case there is no direct answer or approval to do what is requested. This is in conformity with the literature on social influence where direct request are less persuasive (Cialdini and Goldstein, 2004). 
INTERNATIONAL JOURNAL OF ACADEMIC RESEARCH IN BUSINESS AND SOCIAL SCIENCES Vol. 8, No. 12, Dec, 2018, E-ISSN: 2222-6990 @ 2018 HRMARS

Final tendency to persuade is to use the warnings and penalties. These warnings made to noncompliant individuals are not meant to communicate specific cases, but to intimidate. Some warnings refer to monetary penalties, others are in terms of a cost-benefit analysis and the last warnings refer to reputation loss (Myles and Naylor, 1996).

These results show us that some of the tendencies during interactions are more common than others. The use of warnings and penalties is the most common persuasive strategy, followed by information giving and influence to comply and persuasion. However, the most common strategies are not necessarily the most effective because cooperation is more associated with compliance in previous studies (Braithwaite, 2009).

\section{Conclusion}

Overall, this paper adds to the extant literature on tax compliance literature using taxpayer focus groups and analyzing how participants socially influence each other in such communications.

It is important to note that our data is drawn from focus groups from a particular professional group, and that the frequency of use for these strategies may be very different in another settings. It is also worth noting that to extend these findings to all communication about tax is limited.

Accordingly, we hope more researchers will provide further in-depth analyses of tax communication. 7. Acknowledgement

This work was supported by Galatasaray University, Scientific Research Projects Commission under project number 17.102.003. The authors are grateful for the support.

\section{Corresponding Author}

Banu DINCER, Faculty of Economic and Administrative Sciences, Department of Business Administration, Galatasaray University, Turkey. Email: bdincer@gsu.edu.tr

\section{References}

Ashby, J.S., Webley, P., (2008). 'But everyone else is doing it': a closer look at the occupational taxpaying culture of one business sector. J. Commun. Appl. Soc.

Psychol. 18 (3), 194-210

Ashby, J.S., Webley, P., Haslam, A.S., (2009). The role of occupational taxpaying cultures in taxpaying behaviour and attitudes. J. Econ. Psychol. 30 (2), 216-227,

Bobek, D.D., Roberts, R.W., Sweeney, J.T., (2007). The social norms of tax compliance: evidence from Australia, Singapore, and the United States. J. Bus. Ethics

74 (1), 49-64, http://dx.doi.org/10.1007/s10551-006-9219-x.

Boll, K., (2013). Mapping tax compliance: assemblages, distributed action and practices: a new way of doing tax research. Crit. Perspect. Acc.,

Braithwaite, V.A., (2009). Defiance in Taxation and Governance: Resisting and Dismissing Authority in a Democracy. Edward Elgar Publishing.

Cialdini, R.B., Goldstein, N.J., (2004). Social influence: compliance and conformity. Annu. Rev. Psychol. 55 (1), 591-621

Cummings, R.G., Martinez-Vazquez, J., McKee, M., Torgler, B., (2006). Effects of Tax Morale on Tax Compliance: Experimental and Survey Evidence, Retrieved 
INTERNATIONAL JOURNAL OF ACADEMIC RESEARCH IN BUSINESS AND SOCIAL SCIENCES

Vol. 8, No. 12, Dec, 2018, E-ISSN: 2222-6990 C 2018 HRMARS

from http://escholarship.org/uc/item/8sh2w9fp\#page-10.

Fehr, E., Fischbacher, U., Gächter, S., (2002). Strong reciprocity, human cooperation, and the enforcement of social norms. Hum. Nat. 13 (1), 1-25.

Hepburn, A., Potter, J., (2011). Threats: power, family mealtimes, and social influence. Br. J. Soc. Psychol. 50 (1), 99-120.

McKerchar, M.A., (1995). Understanding Small Business Taxpayers: Their Sources of Information and Level of Knowledge of Taxation. University of NewEngland.

Myles, G.D., Naylor, R.A., (1996). A model of tax evasion with group conformity and social customs. Eur. J. Polit. Econ. 12 (1), 49-66.

Ostrom, E., (2000). Collective action and the evolution of social norms. J. Econ. Perspect. 14 (3), 137158.

Potter, J. (1996). Representing Reality. SAGE Publications Ltd.

Potter, J. (2012). Discourse analysis and discursive psychology. In: Cooper, H., Camic, P.M., Long, D.L., Panter, A.T., Rindskopf, D., Sher, K.J. (Eds.), APA Handbook of Research Methods in Psychology, vol 2: Research Designs: Quantitative, Qualitative, Neuropsychological, and Biological. American Psychological Association, Washington, DC, USA, pp. 119-138.

Rincke, J., Traxler, C. (2009). Deterrence Through Word of Mouth (Working Paper Series of the Max Planck Institute for Research on Collective Goods No

2009 04). Max Planck Institute for Research on Collective Goods, Retrieved from http://ideas.repec.org/p/mpg/wpaper/2009 04.html.

Sigala, M., Burgoyne, C.B., Webley, P. (1999). Tax communication and social influence: evidence from a British sample. J. Commun. Appl. Soc. Psychol. 9 (3), Slemrod et al., 2001)

Stalans, L.J., Kinsey, K.A., Smith, K.W. (1991). Listening to different voices: formation of sanction beliefs and taxpaying norms. J. Appl. Soc. Psychol. 21 (2), 119-138,

Torgler, B. (2002). Speaking to theorists and searching for facts: tax morale and tax compliance in experiments. J. Econ. Surv. 16 (5), 657-683,

Torgler, B. (2005). Tax morale in Latin America. Public Choice 122 (1-2), 133-157, 